\title{
TRADE AND THE ENVIRONMENT: COMPETITION, COOPERATION OR CONFUSION?
}

\author{
DONALD MCRAE*
}

The intersection of international trade law and environmental sustainability has been subject to much scrutiny, both in the media and in internationallyconstituted bodies. Views on the impact of trade on the environment range from one of mutual benefit to an assertion of real threat. The author assesses the bases upon which criticism of the WTO is commonly levelled, and provides a reasoned analysis of the nature of the trade and environment debate. In addressing this question, the author examines the purview of the WTO pertaining to trade law, and delineates to what extent environmental protection encroaches upon international trade obligations. To this end, the author considers the means by which conflicts between trade and the environment have been reconciled, and draws attention to issues that obstruct resolution. Lastly, concerns central to the trade and environmental regulatory schemes themselves are raised. The author concludes that the long term viability of international trade equally benefitting the developed and developing world is dependent upon corresponding environmental regulation.
Le point de rencontre du droit commercial international et de la durabilité de l'environnement a été examiné de très près, autant par la presse que par les organismes internationaux. Les points de vue qui ont été donnés sur l'impact du commerce sur l'environnement varient d'un avantage mutuel à une déclaration de menace vraie. L'auteur évalue les bases sur lesquelles l'opposition à l'OMC s'inspire le plus souvent et il donne une analyse raisonnée de la nature du débat autour du commerce et de l'environnement. En abordant cette question, l'auteur examine les limites de l'OMC relativement au droit commercial et il délimite dans quelle mesure le protection environnemental empiète sur les obligations commerciales internationales. C'est pourquoi, l'auteur sur les moyens mis en auvre pour réconcilier les partisans du commerce et ceux de l'environnement et en ce faisant, il souligne les questions gènant cette résolution. Enfin, il soulève aussi les préoccupations qui se trouvent au centre de la réglementation même relative au commerce et à l'environnement. L'auteur conclut que la viabilité à long terme du bénéfice de commerce international autant cu monde développé qu'au monde en voie de développement dépend du règlement environnemental correspondant.

\section{TABLE OF CONTENTS}

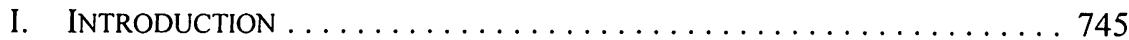

II. THE NATURE OF TRADE . . . . . . . . . . . . . . . . . . . . . . . . . . . . 747

III. THE Legal REgIME FOR TRADE UNDER THE WTO $\ldots \ldots \ldots \ldots \ldots 748$

IV. TRADE Rules AND THE ENVIRONMENT . . . . . . . . . . . . . . . . . 749

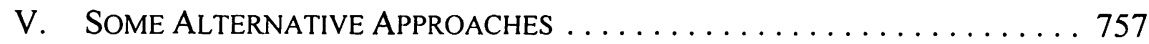

VI. UNDERLYING ISSUES IN THE TRADE AND ENVIRONMENT DEBATE $\ldots \ldots \ldots \ldots \ldots \ldots \ldots \ldots \ldots \ldots \ldots \ldots$

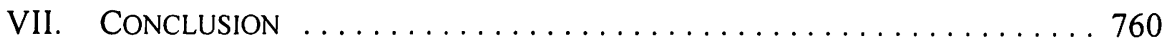

\section{INTRODUCTION}

In launching the Doha round of multilateral trade negotiations, members of the World Trade Organization (WTO) referred to "the mutual supportiveness of trade and the

Hyman Soloway Professor of Business and Trade Law, University of Ottawa. This article is based on lectures delivered at the Universities of Calgary and Alberta, January 29 and 31, 2003 when the writer was the Merv Leitch Q.C. Memorial Visiting Chair. I am grateful to Aliaksandra Logvin for her research assistance. 
environment." In presenting a report at the end of last year on free trade and the environment, the Acting Executive Director of the North American Free Trade Agreement (NAFTA) environmental watchdog, the North American Commission for Environmental Cooperation (CEC), said, "in some circumstances, free trade since NAFTA has also been linked to environmental deterioration." Going further, the Council of Canadians has described the draft Agreement on Free Trade for the Americas as a threat to environmental sustainability. ${ }^{3}$

How does one try to understand a debate that ranges from the polar extremes of the alleged mutual supportiveness of trade and the environment to trade being a threat to the environment? How does one respond to the emotive appeal of protestors in Seattle dressed in turtle suits claiming that an international trade organization, the WTO, was harming sea turtles? ${ }^{4}$ How did an unheard-of international agreement, the General Agreement on Tariffs and Trade (GATT), that for over 50 years had been the forum for governmental officials to engage in arcane discussions about trade issues, suddenly become, under the guise of the WTO, the focus of frequent and often violent protest?

And why is all of this happening now? If trade is bad for environmental sustainability then it has always been so. Trade has been going on for hundreds and thousands of years. It predates the nation state. So are we just waking up to a problem that has been with us for generations? Or is the debate confusing a whole number of issues, and is this debate really a metaphor for a complex series of issues about national and international regulation and the environment, and a surrogate for issues relating to the control of transnational business? ${ }^{6}$ And, does emphasis on conflicts over trade and the environment carry the danger of avoiding many more difficult issues of sustainable development and economic justice across nations and not just within nations?

1 Doha WTO Ministerial Declaration, adopted on 14 November 2001, WT/MIN(01)/DEC/1 at para. 31, online: WTO <docsonline.wto.org/gen_home.asp $>$ [Doha].

2 See also "New report Charts NAFTA environmental record" CEC News (15 December 2002), online: CEC <www.cec.org/news/>; CEC, 2002, Free Trade and the Environment: The Picture Becomes Clearer, online: $\mathrm{CEC}<\mathrm{www} . \mathrm{cec}$.org/pubs_info_resources/>.

$3 \quad$ See Maude Barlow, "What Impact Will the FTAA Have on Canadians?" in The Free Trade Area of the Americas - Part 5, online: The Council of Canadians <www.canadians.org/search_keywords.htm>. See also Maude Barlow, "Stop the FTAA: The Free Trade Area of the Americas and the Threat to Social Programs, Environmental Sustainability and Social Justice in Canada and the Americas," online: The Council of Canadians <www.canadians.org/search_keywords.htm>

$4 \quad$ See Martin Wagner \& Todd Steiner, "World Trade Organization Rules Against U.S. Sea Turtle Protection Law" Newsroom (12 October 1998), online: Earthjustice <www.earthjustice.org>; Peter Fugazzotto, "The Earth Patrol - Sea Turtles and the WTO" World Trade Observer, 29 November 1999, online: Earthjustice <www.earthjustice.org>; Tom Turner et al., "Protesters Shut Down Seattle" World Trade Observer (1 December 1999), online: Earthjustice <www.earthjustice.org>; and Patti Goldman, "The World Trade Organization One Year After Seattle: The Turtles are Still Worried" World Trade Observer (2 December 2000), online: Earthjustice <www.earthjustice.org $>$.

$5 \quad$ See also Brian Smith, "The Chaos Started In Geneva" World Trade Observer (29 November 1999), online: Earthjustice <www.earthjustice.org>; and Bill Walker \& Beth Farmer, "Protesters Remain in Jail as Negotiations and Demonstrations Continue Outside" World Trade Observer (3 December 1999), online: Earthjustice <www.earthjustice.org>.

" The debate over trade and the environment can also be linked to concerns about trade and labour standards and trade and human rights. In this sense it is part of the broader debate over globalization. 
In this article, I try to provide a clearer picture of the trade and environment debate and consider some implications of the intersection of what at one level are two separate intellectual disciplines but, at a more fundamental level, concern both our economic welfare and sustainability of our human ecosystem. I will first look at what we mean by trade and what the WTO does, and then at the content of trade law as it relates to the environment. I will then consider ways in which conflicts between trade and the environment are reconciled or left unresolved, and point out some of the problems that have to be faced in any further reconciliation. Finally, I will refer to some of the neglected but real underlying issues of the trade and environment debate.

\section{The Nature OF Trade}

The word "trade" conjures up many images. What do we mean by trade? In its simplest form, trade is about buying and selling goods across international borders. ' If a farmer in Alberta sells livestock to a neighbour, then that is not commonly regarded as trade. However, if that livestock were to be sold in Montana then it would be part of international trade. Fundamentally, the transaction is the same, we just think about it differently when the transaction crosses a border.

Today, the concept of trade refers to more than the buying and selling of goods across borders. Under the WTO, it refers as well to cross-border movements of services. ${ }^{8}$ But the same point applies. If you fly from Calgary to Ottawa, you have used a domestic service. If you fly from Calgary to Los Angeles, you have used an international service. The service is ro different; we just think about it differently when it crosses a border. The same thing can be said about investment. If you buy shares in Petro Canada, that is a domestic investment; if you buy shares in Exxon, that is a foreign investment. The nature of what you do is the same; but there are cross-border implications.

All of this suggests an important point. When people say that trade is bad for the environment, surely they cannot mean that merely crossing a border is bad for the environment. Instead, what they really mean is that economic activity can be bad for the environment. That, of course, is as true at the domestic level as it is at the international level. In many respects, international trade does not raise fundamentally different issues about environmental protection and environmental regulation than domestic economic activity does give rise to.

7 See Donald M. McRae, "The Contribution of International Trade Law to the Development of International Law" (1996) 260 Rec. des Cours 102 at 110-111 [McRae, "Contribution of International Trade Law"].

\& The Preamble of the Agreement Establishing the World Trade Organization refers to the "trade in goods and services": see Agreement Establishing the World Trade Organization, signed in Marrakesh, Morocco, 15 April 1994, MTN/FA II (entered into force 1 January 1995), reprinted in Joseph F. Dennin, ed., Law \& Practice of the World Trade Organization. Treaties: v. I, Marrakesh Declaration Booklet at 7 [Marrakesh Agreement]. See also Multilateral Agreements on Trade in Goods, Annex 1A to Marrakesh Agreement, online: WTO < docsonline.wto.org/gen_home.asp> [Annex 1A]; and General Agreement on Trade in Services, Annex 1B to Marrakesh Agreement, online: WTO $<$ docsonline.wto.org/gen_home.asp $>$. 
If we did not have borders for economic activity, we would not be talking about trade and the environment. Instead, we would be talking about economic activity and the environment. But whether we are talking domestically or internationally, the problem of economic activity and its impact on the environment remains the same. The question is whether the rules governing international trade make regulating the intersection of economic activity that crosses borders with environmental preservation and protection more or less difficult. To answer this we have to look at the nature of the international regime for trade and the rules that apply under that regime.

\section{THE LEgAL REgIME FOR TRADE UNDER THE WTO}

The WTO arises from an agreement providing for multilateral free trade, although its content is expanded from the traditional content of free trade agreements. ${ }^{9}$ It evolved from an agreement amongst states limiting the ability of governments to interfere with the free flow of goods across their borders to a far more comprehensive trade agreement and institution. The WTO's predecessor, the GATT, set out rules that committed states to adhere to agreedupon tariff levels ${ }^{10}$ and not to discriminate between foreign goods at the border (MFN), ${ }^{11}$ or against foreign goods within domestic markets (national treatment).$^{12}$ It also sought to limit, if not prohibit, import bans and other border restrictions unless they were imposed for a legitimate reason. ${ }^{13}$

That core - to reduce or eliminate border barriers (tariffs and quotas) and nondiscrimination - remains central to the WTO today. There is, of course, much more to the WTO; there are rules on subsidies, ${ }^{14}$ anti-dumping, ${ }^{15}$ agricultural trade, ${ }^{16}$ services, ${ }^{17}$ investment, ${ }^{18}$ and intellectual property. ${ }^{19}$ Throughout all of these areas run the basic pillars of free trade: do not restrict goods at the border and do not discriminate between goods in your domestic market on the ground of country-of-origin.

It is important to note that the rules of the WTO are all about what governments can and cannot do. They are not rules about what corporations can or cannot do. In a review of Naomi Klein's book of essays on the globalization debate, ${ }^{20}$ the reviewer said: "The rules of the WTO give companies the power to override local or national legislation on the

Marrakesh Agreement, ibid.

11 General Agreement on Tariffs and Trade, 30 October 1947, 55 U.N.T.S. 194, art. II "Schedules of Concessions" (entered into force 1 January 1948) [GATT], reprinted in General Agreement on Tariffs and Trade: Basic instruments and selected documents, Vol. IV (Geneva: Contracting Parties to the GATT, 1952-1969).

GATT, ibid., art. I "General Most-Favoured-Nation Treatment".

GATT, ibid., art. III "National Treatment on Internal Taxation and Regulation".

GATT, ibid., art. XI "General Elimination of Quantitative Restrictions".

See e.g. Annex 1A, supra note 8, Agreement on Subsidies and Countervailing Measures.

Ibid., Agreement on Implementation of Article VI of the General Agreement on Tariffs and Trade 1994.

Ibid., Agreement on Agriculture.

General Agreement on Trade in Services, supra note 8.

Annex 1A, supra note 8, Agreement on Trade-Related Investment Measures [TRIMs].

Agreement on Trade-Related Aspects of Intellectual Property Rights, Annex 1C to Marrakesh Agreement, supra note 8 [TRIPS].

20. Naomi Klein, Fences and Windows: Dispatches from the Front Lines of the Globalization Debate (New York: Picador, 2002). 
environment, health and labour and to exact penalties for non-compliance." ${ }^{21}$ That statement reflects a common misconception about the effect of WTO rules. Apart from the very few investment rules available from the WTO and the provisions of the NAFTA Chapter 11, the provisions of the WTO are not directed at corporations. Control over multinational corporations largely rests with the nation state.

What does the WTO do? It provides a forum for discussions between states about trade issues, but these discussions conducted through the various WTO committees and councils are no more than that. The rules set out in the WTO agreements are changed only as a result of new rounds of negotiations, such as those launched at Doha. ${ }^{22}$ The WTO itself does not make any decisions on trade law that are binding on states. ${ }^{23}$

The one exception, of course, is in the area of dispute settlement. The great innovation of the WTO was to establish a system of compulsory dispute settlement. ${ }^{24}$ States have to submit to challenges that their laws or practices are inconsistent with their WTO obligations, ${ }^{25}$ and they are bound by the decisions that are reached. ${ }^{26}$ It is the only truly compulsory form of dispute settlement under international law that exists outside of certain regional systems.

The existence of this dispute settlement system is one of the reasons that trade and environment issues have become more prominent. There is now an opportunity for states to resolve clashes between trade rules and environmental regulation in a dispute settlement forum in which decisions are binding. But the forum is a trade forum, and the decisions are made by the application of rules set out in trade agreements.

\section{TRADE Rules AND THE ENVIRONMENT}

In considering the relationship of trade and the environment, one approach is to view trade per se as harmful to the environment. There are two ways in which the argument can be made. The first is that an international trading regime encourages increased economic activity and any increase in such activity will, in itself, be environmentally harmful. And, of course, such a regime is founded on the truism that much economic activity has the potential for environmental harm, and that the greater the volume of such activity, the greater the potential for harm. A variation of this argument is that international trade has environmentally harmful side effects. The transportation of goods around the world leads to increased shipping and airline activity, all with negative environmental effects. It is no surprise that the CEC Report found evidence of increased air pollution problems at border crossings where cross border

Kerryn Higgs, "Passing the Ammunition" (2002) 20 The Women's Review of Books 5.

22 New WTO negotiations were launched at the Doha Ministerial Conference in November 2001. See Doha, supra note 1; and Doha Developmental Agenda, online: WTO <www.wto.org/english/tratop_e/ dda_e/ dda_e.htm>. See WTO, IO common misunderstandings about the WTO, online: WTO <www.wto.org/english/ thewto_e/whatis_e/whatis_e.htm>.

24 Understanding on Rules and Procedures Governing the Settlement of Disputes, Annex 2 to Marrakesh Agreement, supra note 8 [Understanding on Rules and Procedures]. 
trade has meant increased trucking activity. ${ }^{27}$ If goods were sold closer to their place of production these side effects would be reduced.

The second version of the "trade is harmful for the environment" thesis is what is often referred to as the "race to the bottom." ${ }^{28}$ This is the belief that the competitiveness that free trade engenders will encourage countries to establish lax environmental laws. Industry will flock to places where the least restrictions are imposed on them, while countries with rigorous environmental standards will be drawn into lowering those standards in order to compete.

The problem with this argument is the difficulty in verifying that such a shift has occurred. The "giant sucking sound" so colourfully evoked by Presidential candidate Ross Perot some years ago, according to which, under the NAFTA, industry would be drawn from the United States to Mexico in search of cheaper labour and laxer environmental standards, simply did not materialize. ${ }^{29}$ Nor has competition from Mexico apparently led to a diminution of California's environmental standards. The CEC's Report last year concluded that there was little evidence of any race to the bottom as a result of the NAFTA and that differences in environmental regulation had not been a significant factor in determining where business investments were to be located. ${ }^{30}$

The more specific debate about the clash between trade and environment arises in the context of WTO dispute settlement. For almost 50 years, states applied the rules of the GATT without any serious discussion of the intersection of trade rules with environmental controls. But the matter came to a head in the well-known United States - Restrictions on Imports of Tuna case. ${ }^{31}$ It arose out of an attempt by the United States to use a trade measure - a ban on imports - to achieve an environmental objective: the preservation of dolphins. ${ }^{32}$

The facts are simple. The United States put a ban on the importation of tuna that had been caught by methods that harm dolphins. Dolphins swim with tuna, and traditional tunacatching techniques result in high dolphin mortalities. The United States had imposed controls on its own tuna fleet to prevent the incidental catch of dolphins. It was then seeking to use access to its market to induce other countries to impose similar controls. An import

"Cross-border freight is responsible for 3 to 11 percent of all mobile source NOx emissions in the corridors and 5 to 16 percent of all mobile source PM10 emissions" (see North American Trade and Transportation Corridors: Environmental Impacts and Mitigation Strategies, Final Report (August 2001) at 8, online: CEC <www.cec.org >).

See G. Fredriksson \& Daniel L. Millimet, "Is There a Race to the Bottom in Environmental Policies? The Effects of NAFTA" in CEC, The Environmental Effects of Free Trade: Papers Presented at the North American Symposium on Assessing the Linkages between Trade and Environment (October 2000) 241, online: CEC <www.cec.org $>$.

Ross H. Perot, Save Your Job, Save Our Country: why NAFTA must be stopped - now! (New York: Hyperion Press, 1993) at 41-42, 47.

Free Trade and the Environment: The Picture Becomes Clearer, supra note 2 at 13.

31 Panel Report: August 16, 1991,(1991) 30 I.L.M. 1594 [Tuna-Dolphin I]; United States - Restrictions on Imports of Tuna (1994), Panel Report: DS29/R, June 16, 1994, (1994) 33 I.L.M. 839 [Tuna-Dolphin II]. For a comprehensive analysis of the cases see Richard W. Parker, "The Use and Abuse of Trade Leverage to Protect the Global Commons: What We Can Learn from the Tuna-Dolphin Conflict" (1999) 91 A.J.I.L. 268 
ban is, of course, one of the things that GATT prohibits, so the question was front and center: are trade rules and environmental protection compatible?

The Tuna-Dolphin case is often viewed as representing a clash between trade rules and environmental protection. ${ }^{33}$ In fact, the case highlighted the two fundamental ways in which trade rules and environmental protection can be reconciled. Unfortunately the treatment of both in that case left little cause for optimism. The first way in which conflict between trade and environment can be avoided under WTO rules is by application of the non-discrimination principle. The second way relates to the excuses that a state can invoke for violating its WTO obligations.

In Tuna-Dolphin, the United States claimed that there was no GATT violation because there was no discrimination. Foreign producers of tuna were being treated in exactly the same way as domestic United States producers of tuna were being treated - they both had to use dolphin-friendly catching techniques. In essence, the United States said that what it was doing was preventing the sale in its market of a product that was produced by a process that was environmentally harmful. Traditional tuna fishing is a process that harms dolphins. The United States took the view that it is entitled to differentiate in its market between products that result from a production process that is environmentally harmful and products that have been produced by a process that is not environmentally harmful. It argued that its obligation not to discriminate extended only to products that are "like" each other. The United States' ban on tuna involved making a distinction between products that were unlike - hence there was no discrimination.

The GATT panel rejected that argument. "Likeness," it said, is to be determined by the physical characteristics of a product, not by reference to the manufacturing processes by which a product is produced. Such an approach has often been criticized, ${ }^{34}$ and one can wonder whether it does accord with a commonsense view of the world. Does a system of trade rules that says that states should treat products whose creation harms the environment in exactly the same way as a product whose creation does not harm the environment really make any sense? The Tuna-Dolphin decision threw into doubt the validity of distinctions made by governments between foreign and domestic products on the basis of their harm to the environment.

The second way in which conflict can be avoided between trade rules and environmental protection relates to the area of excuses or exceptions. GATT art. XX permits states to deviate from their GATT obligations for a variety of reasons, the one most closely related to environmental protection being paragraph (g) — where a state has taken a measure "relating

33 Fiona Macmillan, WTO and the Environment (London: Sweet \& Maxwell, 2001) at 70; Carol J. Miller \& Jennifer L. Croston, "WTO Scrutiny v. Environmental Objectives: Assessment of the International Dolphin Conservation Program Act” (1999) 37 Am. Bus. L.J. 73; and Thomas J. Schoenbaum, "International Trade and Protection of the Environment: the Continuing Search for Reconciliation" (1997) 91 A.J.I.L. 268.

34 See e.g. Daniel A. Farber, "Stretching the Margins: The Geographic Nexus in Environmental Law" (1996) 48 Stan. L. Rev. 1247 at 1260; Ilona Cheyne, "Environmental Unilateralism and the WTO/GATT System" (1995) 24 Ga. J. Int'l \& Comp. L. 433 at 450; and Steve Charnovitz, "Green Roots, Bad Pruning: GATT Rules and Their Application to Environmental Trade Measures" (1994) 7 Tul. Envtl. L.J. 299 at 320. 
to the conservation of an exhaustible natural resource." Neither of the Tuna-Dolphin decisions did anything to clarify this provision, which earlier cases had said could be applied only where a measure in question was "primarily aimed" at conservation. The first TunaDolphin panel got sidetracked into the question of whether tuna on the high seas was beyond the jurisdiction of the United States, ${ }^{35}$ and the second panel tried to give a narrow interpretation to the phrase "primarily aimed at."

In the event, the United States' attempt to conserve dolphins did not withstand scrutiny by the GATT. Trade rules and environmental protection, it seemed, were in irrevocable conflict. To some extent it did not matter. GATT decisions were not binding and implementation could be avoided by a recalcitrant state. In fact, the Tuna-Dolphin decisions were never adopted by the GATT Council, and thus were never really part of GATT law. But at another level it did matter. Trade measures, such as import bans, had been adopted in a number of multilateral environmental agreements as a way of ensuring compliance with environmental standards ${ }^{37}$ And the seeming inflexibility of trade rules to respond to legitimate concerns of environmental protection led to a perception that the international trading regime was pitted against responsible environmental protection. For environmentalists, GATT had become GATTzilla! ${ }^{38}$

The WTO, which followed the GATT, was in some respects more problematic. Although it incorporated the GATT, it also expanded the range of trade obligations. It encompassed new areas, and at the same time it introduced binding dispute settlement - trade rules with teeth. So, if trade rules were to trump environmental regulation when the two came into conflict, and trade rules could be enforced, the outlook did not look good on the trade and environment front. If the approach evident in Tuna-Dolphin were to continue under the WTO, then the chances of reconciling trade and environment conflicts would be lost.

In considering WTO law as it affects environmental regulation, it should be noted that the meaning of the WTO rules has been articulated and elaborated upon through the decisions of WTO panels and the WTO Appellate Body. Their decisions are binding because the political organ of the WTO, the Dispute Settlement Body (DSB), must adopt the decisions of panels and of the Appellate Body unless there is a consensus to reject them - that is, a consensus of all members of the DSB, including the state that won the case.$^{39}$ Obviously, such a consensus is never going to happen.

What, then, has been the track record in the development of WTO law on the intersection of trade and the environment? On the question of non-discrimination, there has been no

Tuna-Dolphin I, supra note 31 at paras. 5.30-5.34.

Tuna-Dolphin II, supra note 31 at para. 5.22.

See e.g. Convention on International Trade in Endangered Species of Wild Fauna and Flora, 3 March 1973, 27 U.S.T 1087, 993 U.N.T.S. 243, (1973) 12 I.L.M. 1085 (entered into force July 1, 1975); and Basel Convention on the Transboundary Movement of Hazardous Wastes and Their Disposal, 22 March 1989, UN Doc. UNEP/IG.80/3 (1989), (1989) I.L.M. 657 (entered into force May 5, 1992).

See e.g. Daniel C. Esty, Greening the GATT: Trade, Environment, and the Future (Washington DC: Institute for International Economics, 1994) at 34-35; Michael H. Shuman, "GATTzilla v. Communities" (1994) 27 Cornell Int'l L.J. 527; and Andrew L. Strauss, "From GATTzilla to the Green Giant: Winning the Environmental Battle for the Soul of the World Trade Organization" (1998) 19 U. Pa. J. Int'l Econ. L. 769.

Understanding on Rules and Procedures, supra note 24, arts. 16.4, 17.14. 
formal change from the position in Tuna-Dolphin. However, the possibility that the Appellate Body might deviate from the approach taken in that case arises out of its decision in European Communities - Measures Affecting Asbestos and Asbestos-containing Products. ${ }^{40}$ There, in deciding whether a product that contained asbestos fibres accepted by the Appellate Body as harmful to health was "like" a product without such fibres, the Appellate Body concluded that the inherent harm of the product was part of its essential characteristics and hence was relevant to a determination of "likeness."

Of course, there is a difference between the Tuna-Dolphin case and the Asbestos case. In the former, the product was not harmful in itself; it was just made by a process that was environmentally harmful. In the latter, the product itself was potentially harmful to health; the harm did not result from the process by which it was produced. Nevertheless, Asbestos represents a step forward in the thinking of the WTO Appellate Body about "likeness."

On the question of excuses or exceptions under art. $\mathrm{XX}(\mathrm{g})$, there have been two important cases. In fact, the first case brought to WTO dispute settlement, United Staes - Standards for Reformulated and Conventional Gasoline, involved environmental issues. ${ }^{41}$ It concerned regulations made under the Clean Air Act Amendments of $1990^{42}$ in the United States designed to ensure that impurities in gasoline sold in the United States were held to a certain "baseline" level. However, the United States had established one set of rules for determining "baselines" for domestic refiners and another set of rules for foreign refiners - a classic example of discrimination. It was not surprising, therefore, that the Appellate Body found the United States' measures to be arbitrary and discriminatory within the meaning of the chapeau to $G A T T$ art. $\mathrm{XX}^{43}$

In refusing to uphold the United States' measure, the WTO Appellate Body was not saying that the United States could not reduce impurities in its gasoline; it was just saying that, when reducing the levels of impurities in gasoline, the United States had to treat domestic and foreign producers in the same way. Or to put it another way, the Appellate Body was saying that the United States could not impose the greater burden of improving gasoline on foreign producers of gasoline. In short, the case discloses no evidence of a conflict between trade rules and environmental protection. It is simply a statement of the non-discrimination rule in respect of products - domestic and imported gasoline - that were undoubtedly "like."

The Reformulated Gasoline case started a more flexible approach to the interpretation of $G A T T$ art. $\mathrm{XX}(\mathrm{g})$. It is now clear that $G A T T$ art. $\mathrm{XX}(\mathrm{g})$ concerns general environmental protection - rules relating to the enhancement of clean air or the preservation of shrimp are just as much about the conservation of an exhaustible natural resource (the terms used in art. 
$\mathrm{XX}(\mathrm{g})$ ) as the protection of a resource that is dug out of the ground, ${ }^{44}$ which may have been what the GATT negotiators had in mind in $1947 . .^{45}$

Moreover, as long as there is a substantial or reasonable connection between a governmental measure purporting to protect the environment and conservation of a resource, then it seems that the substantive requirement of GATT art. $\mathrm{XX}(\mathrm{g})$ - that it is a measure "relating to" conservation - is met. ${ }^{46}$ What this suggests is that a measure that has a reasonable or substantial connection with environmental protection will be upheld even if it violates a GATT obligation, that is to say that it is discriminatory or it is in the form of an import ban or other import restriction.

The difficulty with GATT art. $\mathrm{XX}(\mathrm{g})$ is the chapeau. It requires that environmental measures are to be applied in a manner that is not arbitrary or unjustifiably discriminatory and that they are not to constitute a disguised restriction on international trade. The meaning of these terms is difficult to ascertain, and the Appellate Body has not been able to provide much precision in its interpretation or application. ${ }^{47}$ The objective of the provisions is to prevent abuse of the right to deviate from trade obligations, that is, to prevent the use of an environmental pretence for a measure that is essentially providing protection to domestic industry - the sort of thing that was happening in the Reformulated Gasoline case.

Shrimp-Turtle, the second of the two important environmental cases, demonstrates a progression in the application of the chapeau to art. $\mathrm{XX}(\mathrm{g})$. The facts are essentially the same as those of the Tuna-Dolphin case. The United States sought to prohibit the importation of shrimp that had been caught by methods that harmed sea turtles. Again, the United States had applied restrictions to its own industry and was seeking to use access to its market as a way of ensuring that other countries would implement the same or similar measures. In fact, the way in which the United States applied the import restriction was quite arbitrary. Some countries got exclusions where others did not; some were given information and assistance in conforming with turtle-free shrimp-catching techniques, while others were not. ${ }^{48}$ On that ground alone, there were problems with the United States' measure.

However, the principal concern of the WTO Appellate Body was the fact that the United States had adopted this measure unilaterally. ${ }^{49}$ It had neither consulted with other states nor sought to craft its measure in a way that would take into account the different conditions in different countries. Thus, the Appellate Body struck down the United States' import ban. However, it did so in a way which suggested that if the United States had taken reasonable

United States - Import Prohibition of Certain Shrimp and Shrimp Products (1998), WT/DS58/AB/R (Appellate Body Report), (1999) 38 I.L.M. 118 at paras. 129-130 [Shrimp/Turtle].

For the legislative history of art. XX (g) and the view that it had a broad scope: Steve Charnovitz, "Green Roots, Bad Pruning: GATT Rules and Their Application to Environmental Trade Measures" (1994) 7 Tul. Envtl. L.J. 299.

${ }^{47}$ See Donald M. McRae, "GATT Article XX and the WTO Appellate Body" in Marco Bronckers \& Reinhard Quick, eds., New Directions in International Trade Law: Essays in Honour of John H. Jackson (The Hague: Kluwer Law International, 2000) 219 at 219. 
measures to consult with countries that were affected by the ban and had sought to develop a multilateral solution to the problem, the measure might have been upheld.

The decision was welcomed, albeit with a degree of skepticism, by some environmentalists. ${ }^{50}$ They felt that the WTO had created an opening for reconciling trade obligations and environmental measures. And the subsequent history of the Shrimp-Turtle saga suggests that they may have been right. The United States went back and dealt with some of the inconsistencies in its practice and then tried to negotiate a regime for protecting sea turtles with the states involved, but it was not successful. It then re-imposed the import ban. When this was challenged again in the WTO, the measure was upheld. ${ }^{51}$ The United States had taken reasonable steps to establish a multilateral solution and, having done this, it was no longer acting arbitrarily or discriminatorily in applying the measure.

The result in Shrimp-Turtle has implications for the problem of multilateral environmental agreements (MEAs) that incorporate trade measures - that is, environmental agreements that provide for import bans against non-compliant states. Shrimp-Turtle suggests that such agreements, representing a multilateral approach rather than a unilateral one, will be held to be WTO-consistent. Indeed, Shrimp-Turtle would suggest that unilateral measures might still be upheld if there has been a genuine, but unsuccessful, attempt to achieve a negotiated multilateral solution. In short, Shrimp-Turtle opens the way for a true coexistence between trade rules and environmental protection. If a multilateral approach is taken to the development of environmental rules, then those rules will prevail over conflicting trade obligations.

On its face, then, the record of WTO dispute settlement on trade and environment issues seems promising. What are the qualifications?

A major problem for the WTO regarding trade and environment issues is that the organization lacks credibility. Trade agreements are interpreted by panels and an Appellate Body, composed primarily of trade lawyers or government-employed trade policy experts. Those concerned about the protection of the environment are often suspicious of the ability of such individuals to reach the right decision when environmental issues are at stake. Although Shrimp-Turtle may be a step in the right direction, will the Appellate Body get it right next time, particularly when there is a tendency to view environmental measures as thinly disguised protectionist provisions? There is no doubt that measures claimed as environmental measures can be just that. Look at Canada's earlier ban on the export of

Andrea Bianchi, "The Impact of International Trade Law on Environmental Law and Process" in Francesco Francioni, ed., Environment, Human Rights and International Trade (Oxford: Hart, 2001) at 105 [Environment, Human Rights and International Trade]; Massimiliano Montini, "The Necessity Principle as an Instrument to Balance Trade and the Protection of the Environment," in Environment, Human Rights and International Trade at 135; Sarah H. Cleveland, "Human Rights Sanctions and the World Trade Organization," in Environment, Human Rights and International Trade at 235; and Susan L. Sakmar, "Free Trade and Sea Turtles: The International and Domestic Implications of the ShrimpTurtles Case" (1999) 10 Colo. J. Int'l Envtl. L. \& Pol'y 345. 
unprocessed herring and salmon that was sought to be justified before the GATT as an environmental measure! ${ }^{52}$

This mistrust is exacerbated by the secrecy surrounding the WTO dispute settlement process. Panel and Appellate Body pleadings are confidential, although parties can make their own pleadings public. Hearings themselves are held in private. The charge that faceless bureaucrats in Geneva are deciding whether a country can adopt an environmental measure therefore comes as no surprise. Lack of knowledge breeds suspicion and mistrust.

An attempt was made to ameliorate some of this lack of transparency, with the acceptance by the Appellate Body that panels, and the Appellate Body itself, could receive unsolicited "amicus" briefs from anyone, essentially. ${ }^{53}$ Such briefs have been submitted by environmental and industry groups, by private individuals, and even by a state that was not a party or a third party to the procedure. ${ }^{54}$

In form, the process gives the appearance that the views of those from outside the WTO system are being considered. The practice is rather different. First, there is no obligation on a panel or the Appellate Body to consider such a brief. It can receive it and then ignore it. Second, even if a panel or the Appellate Body considers the brief, it is under no obligation to take it into account. In fact, in no case has a panel or the Appellate Body stated that it found such a brief to be helpful. Third, the process does not enjoy the support of member states. In the controversy over amicus briefs at the time of the Asbestos case, only the United States supported the right of the Appellate Body to receive such briefs.

The result is that the WTO has a substantial credibility problem as far as the environmental community and civil society more broadly are concerned. Nevertheless, it is doubtful that the organization will change its approach to transparency in the near future. The Doha negotiations seem unlikely to make progress on trade and environment issues or to

Canada - Measures Affecting the Exports of Unprocessed Herring and Salmon (1988), 35th Supp. GATT B.I.S.D. (1989) 98.

53. In Shrimp/Turtle, supra note 44 at para. 110, the Appellate Body stated, "[w]e find, and so hold, that the Panel erred in its legal interpretation that accepting non-requested information from nongovernmental sources is incompatible with the provisions of the DSU". In Asbestos, supra note 40 at para. 52, it established a special procedure to deal with written submissions received from persons other than the parties and third parties to the dispute (the Additional Procedure). In Hot-Rolled Lead and Bismuth Carbon Steel Products, the Appellate Body emphasized that

[i]ndividuals and organizations, which are not Members of the WTO, have no legal right to make submissions to or to be heard by the Appellate Body. The Appellate Body has no legal duty to accept or consider unsolicited amicus curiae briefs submitted by individuals or organizations, not Members of the WTO. ... We are of the opinion that we have the legal authority under the DSU to accept and consider amicus curiae briefs in an appeal in which we find it pertinent and useful to do so.

See United States - Imposition of Countervailing Duties on Certain Hot-Rolled Lead and Bismuth Carbon Steel Products Originating in the United Kingdom (2000), WT/DS138/AB/R (Appellate Body Report), (2000) 19 WTO Dispute Settlement Decisions 1 at paras. $41-42$ [Hot-Rolled Lead and Bismuth Carbon Steel Products].

54 Morocco submitted an amicus curiae brief, without being not a party or a third party to the dispute between the European Communities and Peru: European Communities - Trade Description of Sardines (2002), WT/DS231/AB/R (Appellate Body Report), (2002) 44 WTO Dispute Settlement Decisions 71. The Appellate Body found that the brief was admissible, but that its contents did not assist in deciding the appeal (ibid. at paras. 153-170, 315(b)). 
open the proceedings of WTO dispute settlement to the public. In part this results from the opposition of many countries, in particular developing countries, to having environmental issues on the WTO agenda.

Developing countries in the WTO are suspicious of linking trade and the environment, suspecting that developed countries are seeking to hold them to standards that were not applied by developed countries themselves when they were gaining their level of economic development. And there is some truth to this. Developed countries have grown rich under a regime of free trade that did not take into account the costs of environmental protection in any comparative advantage calculation. Lax environmental enforcement has historically not been perceived as a subsidy, although that is what it is. Recognition of this fact would entail a substantial rewriting of trade law. ${ }^{55}$

Developing countries also perceive environmental concerns as a new form of protectionism - a strategy among developed countries to allow them to continue to restrict developing country access to the markets of developed states. Alliances between trade unions, whose primary concern is to prevent the exportation of jobs, and environmental groups are viewed with considerable suspicion. It is not difficult to characterize the United States' action in both Tuna Dolphin and Shrimp-Turtle as pitting well-financed United States fishing interests that could absorb the costs of protecting dolphins and turtles against the under-funded developing country fleets that could not afford that cost.

Moreover, to say that the United States can unilaterally adopt environmental measures as long as it negotiates with the other countries first assumes that there is a level playing field in negotiations. Developing countries know that there is not. From their point of view, the United States can go through pro forma negotiations on any issue and then unilaterally implement an environmental measure that deviates from its trading obligations. The approach in Shrimp-Turtle, from the point of view of developing countries, ignores the realities of power.

Furthermore, in respect of the issue of amicus briefs, the distrust of developing countries for non-governmental organizations (NGOs) is a significant factor. NGOs are often seen as well-funded arms of developed countries governments. Giving an NGO the right to submit an amicus brief to a WTO panel, or to the Appellate Body, is perceived by many developing countries as giving developed states the opportunity to submit an additional brief.

\section{Some Alternative Approaches}

Are there alternatives to the ways in which trade and environment issues are currently dealt with in the WTO? Suggestions are sometimes made to integrate environmental matters more directly into the WTO, setting environmental standards and having the WTO dispute settlement process rule on environmental obligations. That approach would recognize the central relationship between trade and the environment and would take advantage of the enforcement mechanism of the WTO to ensure compliance with environmental obligations. An analogy can be drawn in this regard with the TRIPS Agreement of the WTO, whereby a 
trade agreement is used to assist in the enforcement of international intellectual property agreements. The approach is interesting, but unlikely to get support from governments.

The opposite approach is to keep environmental issues out of the WTO completely. They should be dealt with in United Nations Environment Programme (UNEP) or in some new environmental organization that would have its own dispute resolution mechanism. The problem with this approach is that it ignores the fact that regardless of whether there is another international organization dealing with the environment, environmental issues will continue to come up in the WTO. States will adopt environmental measures that conflict with their trade obligations, and they will continue to enter into MEAs that include trade sanctions. Such environmental measures will then be challenged in the WTO. In that way, trade and environment conflicts will still be subject to WTO dispute settlement processes.

An approach to dealing with the impact of trade on the environment that focuses not on regulatory conflict but on the implications for the environment of a trading regime is found in the work of the CEC, the body established under the NAFTA side agreement on the environment. $^{56}$ The function of the CEC is to monitor the environment of the NAFTA area in the light of the trading relationship between the three states. ${ }^{57}$ One specific aspect of its work is providing a mechanism that seeks to ensure that the NAFTA parties enforce their own environmental laws. The $C E C$ has a citizen submission process that allows individuals within the NAFTA area to bring complaints to the Secretariat if a NAFTA party is failing to enforce its environmental laws. ${ }^{58}$ This can lead to an investigation by the Commission and the publication of a report that throws light on whether the party is in fact enforcing its environmental laws. ${ }^{59}$ The process draws attention to the actions of a state rather than compelling it to enforce its laws.

Although the CEC does not provide a mechanism for resolving specific trade and environment conflicts, it does make an important contribution to ensuring that the attractiveness of open markets and foreign investment does not provide an incentive for governments to ignore their own environmental rules. It also provides an important example of how citizens can be involved in a meaningful way in monitoring the activities of the NAFTA governments in respect of environmental protection. It is an important contribution to transparency at the international level.

\section{UNDERLYING ISSUES IN THE TRADE AND ENVIRONMENT DEBATE}

Trade is about enhancing economic welfare. But it is not always seen that way. It is often characterized as relinquishing the control of the state to the control of multinational corporations. Some of the concern expressed about the harmfulness of trade is really concern about the aggregation of wealth by multinational corporations and the lack of control over them when they invest in foreign countries. From an environmental perspective this lack of

North American Agreement on Environmental Cooperation Between the Government of Canada, the Government of the United Mexican States and the Government of the United States of America 13 September 1993 (entered into force 1 January 1994), online: CEC <http://www.cec.org/who_we_are>. 
control both nationally and internationally can lead to a diminishing of environmental controls at home, and the lack of any environmental accountability abroad. To some extent, focusing on this as a trade issue misses the point. Control over multinationals is not something that falls within the purview of the multilateral trading regime. The WTO regulates the conduct of states and not the conduct of private multinational corporations.

In one area, however, the international trading regime does have a direct impact on multinational corporations. That is the area of investment. The WTO has few investment rules, but the rules that do exist are essentially like those of the GATT in respect of goods ${ }^{60}$ - no border restrictions and no discrimination in the domestic market, ${ }^{61}$ along with obligations of transparency. ${ }^{62}$ In the $N A F T A$, the investment obligations are more fully developed and corporations are given direct rights of enforcement against the NAFTA member states under Chapter 11.

Chapter 11 of the NAFTA has been characterized as causing a regulatory chill $^{63}$ on environmental matters because corporations of the other NAFTA parties may sue for compensation if their property is expropriated or if they are denied treatment in accordance with an international minimum standard. The Ethyl Corp. v. Government of Canada (Award on Jurisdiction) case, where Canada settled with a corporation which made such a claim after Canada banned the importation of a gasoline additive, fueled these concerns. ${ }^{64}$ However, although on their facts cases have involved arbitrary and discriminatory action, rather than a genuine non-discriminatory attempt to regulate to achieve an environmental objective, the language used in the decisions in some of the cases is much more problematic. ${ }^{65}$

The implications of investment rules for environmental regulation in Canada and the United States is important, but focusing on the impact of the rights of multinational corporations in the North American context misses the broader international dimensions of the trade and environment conflict. Although it is popular in the globalization debate to characterize free trade as harming developing countries, ${ }^{66}$ an open trading system and the globalization of free trade offer the potential for all countries, including developing countries,

TRIMs, supra note 18.

Ibid., art. 2.

Ibid., art. 6.

See e.g. Lucien J. Dhooge, "The Revenge of the Trial Smelter: Environmental Regulation as Expropriation Pursuant to the North American Free Trade Agreement" (2001) 38 Am. Bus. L.J. 475; Howard Mann \& Konrad von Moltke, NAFTA's Chapter 11 and the Environment: Addressing the Impacts of the Investor-State Process on the Environment (United Nations Environment Programme (UNEP)); and International Institute for Sustainable Development (IISD), 1999), online: IISD <www. iisd.org/publications>.

(1998), (1999) 38 I.L.M. 708 (NAFTA Trib.) [Ethyl]. For the Ethyl settlement, see e.g. Julie A Soloway, "Environmental Regulation as Expropriation: The Case of NAFTA's Chapter 11" (2000) 33 Can. Bus. L.J. 92 at 114

See e.g. Metalclad Corporation v. United Mexican States (2000), Case No. ARB(AF)/97/1, (2001) 40 I.L.M. 36 (NAFTA Ch. 11 Arb. Trib.); and Mexico v. Metalclad (2001), 89 B.C.L.R. (3d) 359 (Sup. Ct.) 664 .

See e.g. Global Policy Forum, "Globalization and the Spread of Poverty" Guardian Online (11 June 2001), online: Global Policy Forum <globalpolicy.igc.org>; and Gobar Times, "Dollar Bananas" Gobar Times (9 September 2002), online: Gobar Times <www.gobartimes.org>. But see Jock Finlayson, "Globalization Myths" Fraser Forum (March 2001), online: The Fraser Institute <oldfraser.lexi.net/ publications/forum/>. 
to benefit from the economic welfare gains of trade. However, developing countries do not benefit as much from the international trading regime as developed countries do. In part this is because developed countries do not open their markets to the products of developing countries. ${ }^{67}$ If developed countries did not subsidize agricultural production and protect their domestic markets, developing countries would be able to enhance their own agricultural economies. They would have better access to export markets and their domestic producers would not have to face competition from subsidized imports. ${ }^{68}$

However, development has environmental implications that cannot be ignored. Development has to be sustainable environmentally. This means that one cannot talk about trade in agriculture separately from the environmental implications of trade in agriculture. At the same time, the world-wide distributional implications of environmental regulation cannot be ignored, and this comes back to the suspicion that developing countries have about developed countries' emphasis on the link between trade and the environment. There is something troubling about a scheme to save turtles if its side effect is that the United States fishing industry prospers but that fishers in Malaysia and Thailand go out of business. Turtles must be protected, but it has to be done in a way that does not place the burden of environmental protection on those who can least afford it. An environmental strategy that allows rich countries to retain their riches but leaves poor countries where they are or even worse off cannot be defended. That is what many developing countries fear will be the consequence of bringing environmental issues more fully into the WTO.

If an open trading system is the way that inhabitants of developing countries are going to gain the economic opportunities that those in the developed world have, then the focus has to be not on decreasing trade, but on ensuring economic activity that will provide sustainable development - whether that activity is within borders or crosses borders. The trade and environment debate, therefore, is about reconciling international and national economic and environmental regulation; it is not about a conflict between trade and environment as such.

\section{CONCLUSION}

Focusing on conflicts between trade rules and environmental protection tends to take attention away from the more fundamental issues of controlling multinational corporations, and achieving sustainable development. Pointing fingers at the international trading regime and at the WTO makes for colourful politics, but often misses the point. Economic activity and a multilateral trading regime will only be viable in the long term if they go in hand with regulatory regimes that preserve the sustainability of our human ecosystem. Equally, international environmental regimes will only be viable if they complement and do not negate a multilateral trading regime that sustains economic well-being and permits those in the developing world to share the economic benefits that those in the developed world have. (2002) at 5, online: CED <www.ced.org/pubs.shtml >. 